\title{
Challenges to Labour Law
}

\section{目 Wolfgang Däubler}

Professor, Labour Law, Civil Law and Economic Law Department, University of Bremen. Address: Bibliothekstraße 1, 28359 Bremen, Federal Republic of Germany. E- mail: daeubler@uni-bremen.de.

\section{䧳 Abstract}

The article deals with three main challenges to labour law referring especially to the German experience. The world-wide market induced enterprises to relocate their production and to reduce labour costs at home. In Germany, a quite indirect way of exercising pressure on the workers was developed; counter-measures were rare and did not really change the situation. TTIP and CETA will worsen the situation because national sovereignty in social and environmental questions will fade away. The second challenge comes from inequality existing among workers as well as in society as a whole. There is a scission between very wealthy people on one side and people becoming poorer and poorer on the other side. Labour law has not yet developed the instruments to realize more equality among workers but some ideas are discussed. The third challenge is the digitalisation of many activities; they are no more bound to certain places or certain times of the day. The "freedom" to work at any moment and at any place entails very long working hours, work at night and work on Sundays. Legal rules on working time lose more and more there importance. A solution can be the right of workers' representatives to discuss the tasks given to individual workers, but other means are examined in the article, too. The internet makes crowdworking possible - a new form of work which is currently not covered by labour law.

\section{O-1国 Keywords}

globalisation, inequality, digitalisation, crowdworking, excessive working time, scission among workers, selfemployed persons.

Citation: Däubler W. (2016) Challenges to Labour Law. Pravo. Zhurnal Vysshey shkoly ekonomiki, no 1, pp. 189-203 (in English).

DOI: 10.17323/2072-8166.2016.1.201.215

\section{Introduction}

My subject is quite a broad one. I may be permitted to concentrate on a discussion which has started in my country. It may sometimes happen that social phenomena are less recognized in one country whereas they are at the centre of scientific interest in another. In other cases, the point of departure may be the same, but the way of dealing with problems can be very different. So I have to beg your pardon if I describe a topic which may be quite new for some of us, but may be rather well-known to other people. My German style of dealing with problems and theories is often linked to examples; to develop new categories - typical e.g. for a French approach - will remain our task for the future when we have completely understood the reality.

In Germany we see three challenges to labour law.

- The first one is globalization in the sense that markets for products and for investments are becoming more and more open; the last obstacles to international commerce being taken down. 
- The second one is inequality which exists among workers as well as in society as a whole.

- The third one is the growing digitalisation of work which questions the separation between workplace and private life.

I will deal with these three points adding some reflexions about possible reactions of workers, their unions and their networks.

\section{Globalisation}

To be exposed to world-wide competition is nothing new for German enterprises. It may be sufficient to remember that during the 1970s large parts of the German textile industry were transferred to low-wage-countries ${ }^{1}$. But the situation changed after 1990. Low-wage-countries were quite nearby in Eastern Europe right on the doorstep. What was even more important was the change in power-relations. Before 1990, social policy was determined largely by political reasons. To treat the working class badly would have meant running the risk that sections of it would develop sympathy for the system in the East. Now this "danger" has disappeared; the market has been given free rein.

\subsection{Loss of Workplaces}

Workplaces were lost and still are. In some fields, the same tasks can be fulfilled at lower costs in other countries. The difference in wages may be so high that even lower productivity does not matter. A manager of a German firm once told me: "A German engineer works as much as five Indian engineers. But the money I have to pay to him would be sufficient to pay ten Indian engineers". What is the practical effect of such a "theory"? Workers and their unions can at least be threatened by the relocation of the plant or a part of it. In some cases the production will be effectively transferred to another country. The difference in wages is, however, only one factor in decision-making process. What is the infrastructure like in the foreign country? Are there enough qualified people available? Are there any problems with public safety? Is there a reliable administration or will it only do its job on the basis of bribes? Are there "tariffs" one has to pay for a licence or permission? In some less complicated cases production is transferred to another country in order to serve the local market therefore reducing growth at home.

\subsection{Intensification of Work}

Today, the typical case sees no more relocation of plants. In my example, the message given to the engineers is: "You are good but be better". International competition puts pressure on workers to perform. Counter-pressure is dangerous because workers never know whether the next task in the group of enterprises will be given to an Indian or Chinese subsidiary.

\subsection{Reducing Labour Costs}

Nowadays in Germany, labour costs can no longer be reduced by just putting away collective agreements. That would disturb the social partnership existing between employers and unions and would not even be welcomed by the employers who do not want state intervention

${ }^{1}$ The article is based on a speech delivered on September 25, 2015 in Venice. See: Fröbel F., Heinrichs J., Kreye O. Die neue internationale Arbeitsteilung. Reinbek, 1977. 
in such a field. There is a more sophisticated way; it was based on the so-called Hartz-Reforms in 2003 and $2004^{2}$. Two points need to be stressed upon.

Temporary agency work was "liberalised". A work assignment with another employer was permitted without any time limit. In this way, an employer could replace employees with temporary agency workers if there was a vacancy in his plant. Unlike in France, temporary agency workers earn $30 \%$ to $40 \%$ less than normal workers; so it may be profitable to increase the number of them. Indeed, after 2003 there was an increase from about 200,000 people to 850,000 people in $2007^{3}$. The law provided for equal pay and equal treatment but these principles could (and can) be sidestepped by collective agreements. The unions collaborated in concluding agreements which fixed the traditional conditions of temporary agency workers. The existence of low-paid workers put pressure on the whole working class being threatened by the employment of more and more temporary agency workers.

The second point is the reduction of the "social network". Before 2003, an unemployed person received unemployment benefits for one to two years depending on their age and years of service. When this time was over and no new job was found the person concerned received "unemployment aid" without any time limit; it was $50 \%$ of the former income after deductions and $57 \%$ if the person had to take care of a child. The person was not obliged to sell his or her assets like an apartment and a car or to give back a life insurance policy to the insurance company. All this was abolished by the so-called Hartz legislation. Former income no longer played any role. Everybody received 345 Euros a month (plus rent for a modest apartment and costs for heating); with few exceptions, assets including life insurance had to be sold before getting any money. This was a horrible come down for most of the people concerned. Workers with jobs were quite anxious about finding themselves in a similar situation.

In the years between 2000 and 2008 the effective net wages went down by $0.8 \%$ because the inflation rate was higher than the average wage increases ${ }^{4}$. The lowest $20 \%$ of wage earners lost $2.5 \%{ }^{5}$, while the highest $10 \%$ were even better off. It took until 2014 , before the average real wages were higher than in $2000^{6}$.

\subsection{Counter-Measures?}

International labour law does not offer any solution to these problems. There is no ILO convention on the relocation of enterprises. The OECD Guidelines on multinational enterprises ${ }^{7}$

\footnotetext{
${ }^{2}$ Hartz was a member of the board of Volkswagen responsible for human resources and chairman of a Government's commission for the reform of the labour market. Some years later, he lost his job for corruption and was condemned to one year of prison (the sentence being suspended).

${ }^{3}$ See: Bundesagentur für Arbeit. Der Arbeitsmarkt in Deutschland - Zeitarbeit - Aktuelle Entwicklungen. Nürnberg, 2015. P. 6 available at: // http://statistik.arbeitsagentur.de/Statischer-Content/Arbeitsmarktberichte/ Branchen-Berufe/generische-Publikationen/Arbeitsmarkt-Deutschland-Zeitarbeit-Aktuelle-Entwicklung.pdf (accessed: 10.01.2016)

${ }^{4}$ See: European Union publication. Available at: http://www.eu-info.de/deutsche-europapolitik/umfragenstatistiken-deutschland/reallohn/ (accessed: 12.11.2015). Germany was the only country in Europe with a decrease of real wages in the period between 2000 and 2008.

${ }^{5}$ Frankfurter Allgemeine Zeitung. Available at: htpp://ww.faz.net/aktuell/wirtschaft/wirtschaftspolitik/ lohnunterschiede-in-deutschland-gehen-weiter-auseinander-13490563/reallohnentwicklung-in-13490600. html (accessed: 12.11.2015)

${ }^{6}$ Der Spiegel. Available at: http: // www.spiegel.de/wirtschaft/service/realloehne-in-deutschland-liegenhoeher-als-im-jahr-2000-a-1019175.html (accessed: 5.01.2016)

${ }^{7}$ Available at: http://www.oecd.org/daf/inv/mne/48808708.pdf (accessed: 5.01.2016)
} 
prohibit using a possible relocation as a threat during negotiations with workers' representatives about other subjects, but relocation as such is not restricted, and the "guidelines" contain no binding rules but rather only lead to a mediation process with a competent national body. Intensification of work and fostering a sector of low-paid workers are not subjects dealt with at ILO Conventions.

National law may offer some more help. Can the right to strike be useful in such cases? According to the German courts, a strike is legal only if it is led by a union and if it aims at the conclusion of a collective agreement. The essential question is, whether the relocation of a plant may be regulated by collective agreement. Must such a decision be considered as a management prerogative? The Federal Labour Court found a diplomatic solution ${ }^{8}$. It stated that unions and employers are allowed to conclude collective agreements about the consequences a relocation of the plant may have on the situation of the workers. In the concrete case, the union had claimed to extend the periods of notice to three years; in addition the employer should pay the costs to the workers in regards to getting a new professional qualification. Those who did not take this opportunity should receive a severance pay which amounted to two monthly salaries for each year of service. Such demands were considered to be legal - even if their realization would make the relocation economically unreasonable. By increasing demands, the union can begin negotiations about the relocation of the plant as such.

As to the intensification of work, labour law is not well-prepared. The law about working time only contains notions like on-call duty and standby service which describe a kind of "reduced" work. If the normal standard is exceeded, we cannot find any category like "uninterrupted work" or "heavy work". The only exception can be found in collective agreements which provide an additional payment for dangerous or especially unpleasant work. This problem will reappear in the context of digitalisation; it shall, therefore, be dealt with later.

The Hartz legislation was challenged in the Constitutional Court because Parliament had not paid sufficient attention to the situations of the persons concerned. The deputies had, e.g., neglected the need to spend money on further education, which was especially severe because children got (depending on their age) $60 \%$ or $80 \%$ of the sum given to adults. A child talented in music or a special kind of sport would have no chance to develop his or her skills. The Constitutional Court declared the law to be unconstitutional ${ }^{9}$, a decision which brought some improvements afterwards but which could not change the political impact the legislation had on the working class.

\subsection{Foreign Owners of German Enterprises}

In open markets, enterprises may be bought by foreign investors. If this takes place, labour law can no more be applied in the same way as before, i.e. in relation to a national employer: if the real decision-makers are in the U.S. or in Japan, collective bargaining in the traditional sense is no longer possible. If the other side of the bargaining table has no mandate, negotiations become a pure formality. There is only the alternative, to accept the proposals coming from overseas or to go on strike. In most cases, the second solution cannot be practiced for different reasons. Under these circumstances, unions can only appeal to the foreign managers to improve the human relations in the enterprise. Such a kind of appeal brings acceptable solutions in a few cases but as a rule has no effect. As first experiences show, only Chinese investors

\footnotetext{
${ }^{8}$ BAG (= Bundesarbeitsgericht $=$ Federal Labour Court) 24. 4. 2007 - 1 AZR 252/06 - NZA $(=$ Neue Zeitschrift für Arbeitsrecht). 2007, p. 987.

${ }^{9}$ BVerfG 9. 2. $2010-1$ BvL 1/09. Neue Juristische Wochenschrift. 2010, p. 505 et seq.
} 
take a different attitude. They accept German rules on collective bargaining and codetermination. They are interested in the special qualifications and working attitude of the German workforce. Workers are often considered by them to be the most valuable part of the enterprise, which can greatly help to develop the Chinese parent company ${ }^{10}$.

\subsection{TTIP and CETA}

The planned "Transatlantic Trade and Investment Partnership" (TTIP) between the EU and the US and the "Comprehensive Economic and Trade Agreement" (CETA) between the EU and Canada bring a new dimension into the globalised market. Free commerce is intensified once more, bringing additional competition (and more pressure to perform) to the workers. But the "Free Market" ideology is so strong, that even unions and left-wing parties accept it as such. The criticism concentrates, however, on two other important points. The unified market will put social and environmental standards at risk; Europe will be forced to follow the example of the United States in order to remain competitive. The second point is even more embarrassing. The nation state will be liable and obliged to pay damages if "legitimate expectations" of investors are not met. There is the current example of the Swedish company Vattenfall asking for 4 billion Euros in damages because Germany decided to renounce nuclear power plants in the future ${ }^{11}$. Whether "legitimate expectations" have been met or not, will be decided by arbitration courts in an in transparent procedure. The EU Commission has presented a paper to be used in the negotiations with the United States which wants to install international courts, but the problem remains that the nation state loses a lot of its legislative power. Would it not be too dangerous to increase the minimum wage by $30 \%$ because investors could not foresee it? What about enlarging the fields in which codetermination of works councils takes place? Would a better protection against dismissal still be possible? If there even a small risk that Germany would be obliged to pay billions of Euros as damages to foreign investors, the Parliament would renounce such a kind of legislation. National sovereignty in social and environmental questions will fade away.

\section{Equality - a Lost Value?}

Inequality is a consequence of globalisation but it cannot be explained exclusively in this way. In Germany, you can find inequality among workers as well as inequality in society as a whole. What is the current role of labour law in this field and what will its future function be?

\subsection{Inequality Among Workers}

Labour law permits the creation of precarious jobs which cannot guarantee an adequate economic existence for the individual worker and his or her family. Traditionally, fixed-term contracts could be concluded only if there was objective reason (in German: Ein sachlicher Grund) to do it. Replacing worker who is absent for maternity reasons or for educational leave was a typical situation; another one was the probation period. Since 1985, the legislator has admitted fixed-term contracts without objective reason; the idea was to give an incentive to employers to

${ }^{10}$ For more details see: Däubler W., Müller H. Chinesische Arbeitgeber in Deutschland. AiB (=Arbeitsrecht im Betrieb). 2015, issue 2, p. 33.

11 Available at: http://www.zeit.de/wirtschaft/2014-03/investitionsschutz-klauseln-beispiele/seite-2 (accessed: 5.01.2016). The legal basis is the so-called Energy Charter containing comparable provisions as CETA. 
recruit more people. Whether this effect took place was never proven empirically, but the legislator continued in this way. Today, a fixed-term contract without objective reason is possible for a period of two years, which can be split into four parts ${ }^{12}$. The only condition is the absence of a former labour relationship with the same employer, a rule which the Federal Labour Court has restricted to the absence of a labour relationship during the last three years ${ }^{13}$. In 2012, about $8.5 \%$ of all workers had a fixed-term contract; twenty years ago the number was much lower ${ }^{14}$. As the workers normally want to keep their jobs, he or she depends completely on the employer who is free to give a new contract or to refuse it. Of course, no discrimination would be allowed, but intelligent employers avoid any suspicion going in this direction. The worker is well advised not to have conflicts with the employer; consulting the works council in a personal matter or joining the union would be seen by many employees as a dangerous behaviour. As for payment and working conditions, the worker is entitled to the same rights as workers with an open-ended contract but you will find only a very small number of judgments dealing with this topic.

Temporary agency workers have already been mentioned. Lower wages and worse working conditions are characteristic of this group of workers. According to a report by the Federal Government, $50 \%$ of all these labour relationships end within three months ${ }^{15}$. Their legal position has been improved during the last years but there is still a large gap between regular workers and temporary agency workers.

Part-time workers are no uniform group. Some of them work thirty hours per week and receive a good salary. On the other side is the large group of persons in marginal employment, whose earnings are below the threshold of 451 Euros per month. They are normally not included into the social security system and their income is obviously insufficient for their living ${ }^{16}$. Between the two groups one can find part-timers who are covered by the social security system but who can live only with the support of family or the state.

These three groups of atypical workers are normally seen as a synonym for precarious work. But there are two important additional groups who are in a comparable situation.

Full-time workers with an open-ended contract may work in a small plant with less than eleven workers: They have almost no protection against dismissal, collective agreements do not apply and a works council does not exist ${ }^{17}$. There legal situation is assimilated to what the rule was before the First World War. The only exceptions are the protection for maternity and for the disabled (and some improvements in the social security system). If such a worker gets a salary near the legal minimum wage he or she can be considered to be in a precarious situation, too.

Self-employed workers make up $12 \%$ of the active population ${ }^{18}$. Those without employees make up 7\%; from 2000 to 2010 their number increased from 1.8 to 2.5 million persons ${ }^{19}$. In the German system, they are regularly not included in the social security system (exceptions: social

${ }^{12}$ Article $14 \$ 2$ Teilzeit- und Befristungsgesetz (Law on part-time work and fixed-term contracts).

${ }^{13}$ BAG 6. 4. 2011 - 7 AZR 716/09 - DB (= Der Betrieb) 2011, p. 1811.

14 Available at: // http://www.sueddeutsche.de/karriere/angaben-der-bundesregierung-zahl-der-befristeten-arbeitsvertraege-in-deutschland-gestiegen-1.1931132 (accessed: 12.11.2015)

15 Available at: //http://www.bmas.de/SharedDocs/Downloads/DE/aueg-bericht-12.pdf?_blob=publicationFile. (accessed: 12.11.2015)

${ }^{16}$ For details see Däubler W. Das Arbeitsrecht. 11. Aufl. Frankfurt/Main, 2015. Rn. 1107 et seq.

${ }^{17}$ In theory, a works council could be elected if the plant has at least 5 employees; a collective agreement can be applied, if the employer is a member of the employers' association. These are very rare exceptions.

${ }^{18}$ DIW-Wochenbericht 7/2013. S. 5 (DIW = Deutsches Institut für Wirtschaftsforschung)

${ }^{19}$ DIW-Wochenbericht 7/2013. S. 3. 
security for artists, members of liberal professions like doctors, lawyers, architects etc.). They are not covered by labour law irrespective of their economic situation. If they depend economically on one enterprise or on the administration they are considered to be a person "assimilated to an employee" (in German: Arbeitnehmerähnliche Person). To this group of persons some labour law rules apply. The most important ones are the right to a minimum leave of four weeks and the right to be protected by collective agreements. But all the other important rules are not applicable: no protection against dismissal, no integration into the system of works councils. In practice, collective agreements are concluded only for the collaborators of radio and television in the public sector. For employers, self-employed people are quite appealing because contributions do not have to be paid into the social security system for them.

\subsection{Inequality in Society}

Inequality among workers has repercussions on the whole of society. People who have no sufficient living income but are able to work get the minimum benefit described above ${ }^{20}$. They numbered 4.372 million in $2015^{21}$. Those not able to work receive "social aid" as welfare recipients; this amounted to 370,000 in $2014 .^{22}$

The group of "working poor" who do not even earn enough money to reach the minimum standard of living for themselves and for their families comprises 1.317 million people. Among them were 218,000 full-time employees ${ }^{23}$. They receive benefits to top up their income to subsistence level ${ }^{24}$. This is a form of combined wages giving an incentive to employers to pay very low salaries in fields where you need no qualification to do a job.

According to the Federal Statistical Office, $14.5 \%$ of the population are threatened by "poverty"; the poverty line is drawn at 917 Euros a month ${ }^{25}$. An EU survey has found that $16.1 \%$ are in this situation. Both agree that the percentage has grown during the last ten years despite of the economic boom.

The distribution of wealth is even much more unequal. The richest 80,000 people $(0.1 \%$ of the population), have sixteen times more property than the poorer half of the whole population - approximately 40 million people ${ }^{26}$.

Inequality is not only a problem of justice between individuals. Wilkinson and $\mathrm{Pickett}^{27}$ have analysed a large quantity of empirical research whose results are quite clear: in developed countries with a high degree of inequality, criminality is high, physical health and life expectancy are low, and drug use is high. On the other hand, countries with a lower degree of inequality have less criminality, a better health situation, higher life expectancy and drugs are less common. This

\footnotetext{
${ }^{20}$ See Chapter 2.3.
}

${ }^{21}$ Available at: // http://de.statista.com/statistik/daten/studie/1396/umfrage/leistungsempfaenger-von-arbeitslosengeld-ii-jahresdurchschnittswerte/ (accessed: 12.11.2015)

${ }^{22}$ Available at: http://www.welt.de/wirtschaft/article133730244/Zahl-der-Sozialhilfeempfaenger-steigt-auf-Rekordhoch.html

${ }^{23}$ Available at: http://www.sozialpolitik-aktuell.de/tl_files/sozialpolitik-aktuell/_Politikfelder/Arbeitsmarkt/Dokumente/Beschaeftigte-Arbeitslosengeld-II-Bezieher-Vollzeit-Teilzeit.pdf (accessed: 12.11.2015)

${ }^{24}$ In German they are called "Aufstocker".

${ }^{25}$ Available at: // http://www.sueddeutsche.de/wirtschaft/statistisches-bundesamt-mehr-deutsche-von-armut-bedroht-1.2623426 (accessed: 12.11.2015)

${ }^{26}$ Available at: http://www.spiegel.de/wirtschaft/soziales/vermoegen-sind-in-deutschland-sehr-ungleichverteilt-a-1051286.html (accessed: 12.11.2015)

${ }^{27}$ Wilkinson R., Pickett K. The Spirit Level. Why Quality is Better for Everyone. London, 2010. 
is not a question of national life style, because the same results can be seen in the United States: states with more inequality, like Texas, have a higher number of criminals, more violence etc.

\subsection{Impacts on Labour Law}

Today, "equal treatment" has become a fundamental feature of labour law. ${ }^{28}$ But the "unit" in which equality has to be observed, is the plant or the enterprise. Some labour lawyers may include groups of enterprises but that would be the utmost limit. The problems described here are in no way reached by the labour law principle of equality. Even anti-discrimination law stops at this point. Those who like the details of ECJ- judgments will perhaps remember the Defrenne- case. In Defrenne $\mathrm{II}^{29}$ the court stated:

"It is impossible not to recognize that the complete implementation of the aim pursued by Article 119, by means of the elimination of all discrimination, direct or indirect, between men and women workers, not only as regards individual undertakings but also entire branches of industry and even of the economic system as a whole, may in certain cases involve the elaboration of criteria whose implementation necessitates the taking of appropriate measures at Community and national level."

Article 119 (which is today Article 157 of the Treaty) aims at wage equality between men and women throughout the economy. A good principle which has been completely forgotten in the ensuing forty years: who did ever refer to it? On the contrary, the single-source-theory requires that one body is responsible for the discrimination ${ }^{30}$. If a female civil servant and a male public employee do the same job but get different salaries, the equality principle will not apply if the wages of civil servants are fixed by law whereas the salaries of public employees are defined by collective agreement ${ }^{31}$. The only way to extend the field of application of the equality principle is the conclusion of collective agreements for a sector of the economy. But in Germany it would be impossible to find collective agreements for the whole economy which would reduce the gap between different sectors. A "solidarity wage policy" was tried in Sweden some 30 years ago ${ }^{32}$, but no longer has any current impact. Unions are not strong enough to tackle such problems.

\section{Work in the Digitalised World}

\subsection{The Appearance}

The digitalisation of work is a process linked to the use of certain devices like laptops, smartphones and tablet computers combined with access to the internet. If one considers professional and private activities, only a small minority does not use the Internet in Germany. In $2014,78.71 \%$ of the population over 14 years old were users, compared to $60.2 \%$ in 2007 and

\footnotetext{
${ }^{28}$ See on a comparative basis Hepple B. Equality at work / Hepple B., Veneziani B. (ed.). The Transformation of Labour Law in Europe. Oxford, 2009, p. 129 et seq.

${ }^{29}$ Judgment, April 8, 1975. Case 43/75.

${ }^{30}$ ECJ 17 September 2002 - C-320/00 - NZA 2002, 1144.

${ }^{31}$ BAG 3. 4. 2003 - 6 AZR 633/01 - NZA 2003, 1286.

${ }^{32}$ See Pfromm H.-A. Solidarische Lohnpolitik. Köln, 1978; Schulten T. Solidarische Lohnpolitik in Europa. WSI-Diskussionspapier № 92. Düsseldorf, 2001.
} 
only $37 \%$ in $2001^{33}$. According to the Federal Statistical Office, the number was smaller in the workplaces; only $64 \%$ of workers used a computer and $55 \%$ had access to the internet ${ }^{34}$. Mobile use in general increased from $18 \%$ in 2011 to $60 \%$ in $2013^{35}$.

A person who carries a smartphone or a tablet computer is always reachable, theoretically around-the-clock. A second change is even more important: the person concerned is able to start working at once. Where he or she stays plays no role: in a hotel room, on the train, in the lounge at the airport. If these possibilities are really used, the boundaries between work and spare time are becoming blurred. The internet removes spatial and systematic barriers ${ }^{36}$. The implications for labour law are considerable.

\subsection{Working Time Problems}

\subsubsection{The Facts}

Working time legislation regulates the duration of work and the work schedule, putting limits upon both of them. If work is done in a factory or in an office, it is quite easy to find out how many hours the person has worked, beginning at eight oclock in the morning and ending at five o' clock in the evening. The working time law establishes clear limits which can be controlled easily. But how can one control how many hours a person has worked at home, on the train or in the hotel room? Technically, it would be possible to register all activities on a computer with an internet connection. But this would lead to complete supervision of the individual and it would be incomplete because the time spent, e. g., in preparing work with electronic media, will not be included. In practice, this system is normally not used. More and more people just receive a task which has to be fulfilled by a certain date - it is up to the worker to decide when and where he will do his job. We call this form of working in Germany 'trust based working time' ("Vertrauensarbeitszeit").

As far as we know, there are many cases in which the limits for weekly working hours are neglected. Based on the EC-Directive, the average working time per week is forty-eight hours, but this average has to be attained over just six months. In some weeks people are entitled to work sixty hours if in other weeks they reduce their work, so that the average is reached. Obviously, the legislation offers a lot of flexibility, but some limits have to be observed. These limits are no more effective under the new conditions. We have no conclusive information about the real behaviour of workers but there are a lot of indications that some people work eighty to one hundred hours per week. This may depend on the issue of the workload being too big to be completed within forty or forty-eight hours. Another factor may be the worker is highly motivated and considers his work at the computer to be much more important than his private life. Finally, people are not accustomed to making their own schedule. Starting at kindergarten, continuing at school and finally working in an office or a factory, the individual has to follow a schedule fixed by other people. Doing it yourself has to be learned - time management is not a

\footnotetext{
${ }^{33}$ Available at: http://de.statista.com/statistik/daten/studie/36146/umfrage/anzahl-der-internetnutzer-indeutschland-seit-1997/ (accessed: 12.11.2015)

${ }^{34}$ Statistisches Bundesamt, Unternehmen und Arbeitsstätten. Nutzung von Informations- und Kommunikationstechnologien in Unternehmen. Wiesbaden, 2013. S. 10, auch zum Folgenden.

${ }^{35}$ Statistisches Bundesamt. Op. cit. P. 6.

${ }^{36}$ The German expression is "Entgrenzung” which literally means “delimitation”. See Däubler W. Entgrenzung der Arbeit - ein Problem des Arbeitsrechts? Soziales Recht. 2014. P. 45 et seq.
} 
natural gift. There is therefore quite high risk that the duration of working time is far from the legal limits; the provisions of the working time act lose their practical importance.

The problem of duration, however, is not the only one. You will find in the law a mandatory rest period (eleven hours in Germany with some exceptions). But what happens if the supervisor asks the employee at nine oclock in the evening to prepare a power-point presentation for a meeting at half past eight the next morning? The employee will do it and finish his work by eleven oclock in the evening. Will he then come to office at ten oclock next morning, thus invoking the legal rule? Of course, not. Nobody would behave in such a way reality is stronger than the law.

What about Sundays and annual leave? People check their e-mails, which is part of their job. Nobody will criticize them if it is done voluntarily. But many people do it because they know that on Monday (or after return from the holidays) they will have so much to do that they will find no time for their e-mails. Is it not a better feeling if you go into the office on Monday morning knowing that you have already done a good portion of your work? It is also possible that the boss phones during the annual leave asking for information or for a "small" task to be completed. What are the legal consequences if there are two or three phone calls in one day?

\subsubsection{Possible Solutions}

German employers have discovered these problems and are asking for a reform of the working time Act. One group of human resources specialists wants to increase flexibility: twelve hours (instead of ten) per day, and an average of sixty hours per week should be permitted. Control should not be improved but reduced - provisions that now oblige the employer to document if an employee works longer than eight hours a day should be abolished ${ }^{37}$. It will be difficult to realize these demands because the eight-hour day has a high symbolic value for workers. Another demand is to make the mandatory rest period more flexible; eight hours instead of eleven, while the average over six months should be eleven hours.

In my view, the main problem is not the working time Act and its detailed provisions. Why should we modify rules that are less and less observed? The main problem is the quantity and the intensity of work which has to be done by an employee. Are there any labour law provisions that would prohibit giving a worker a task which he can fulfil only by working eighty hours during six weeks? You will find no such provision in the working time Act. The only source is individual labour contract law: the employee has to work according to his individual faculties without endangering his health ${ }^{38}$. Putting aside any extreme cases, a worker will never invoke this rule pretending that his health will be in danger if he fulfils the tasks he was given. What we need are limits established by collective agreements, by codetermination or by labour inspection. If we can no longer really regulate the duration of the work, we have to deal with its quantity.

In some a few sectors of the economy, collective agreements have established rules about the minimum number of persons who have to fulfil a certain task. The most important example is found in the printing sector where certain machines require the presence of at least five or six persons. This is one way to reduce an individual's workload. Recently, the service union has picked up on this idea in a large hospital in Berlin: in intensive care units one nurse per two beds, in normal cares units one nurse per five beds. These demands were underlined by a strike

${ }^{37}$ Available at: // http://www.bvau.de/files/Daten/content/Dokumente/BVAU_Eckpunkte\%20Arbeitszeit_ August\%202015.pdf (accessed: 12.11.2015)

${ }^{38}$ See Preis V. in: Müller-Glöge R., Preis V., Schmidt L. (eds.). Erfurter Kommentar zum Arbeitsrecht. 16 Aufl. München, 2016. \$611. BGB Rn. 641. 
which was considered to be legal by the regional labour court ${ }^{39}$. The compromise was that the demand was fulfilled as with the intensive care units; for the normal care units, the number of nurses has to increase considerably. One idea is to transfer such a solution to other fields in which the quantity of work can be evaluated.

Another experience could be useful too. In most German firms, one can presently find time accounts which document the hours an employee has worked. Normally they show time credits, i. e. any additional working hours the employee has performed. In some shop agreements concluded between employer and works council you can find two rules:

If the average time account of a group of ten or twenty workers shows a credit of hours and one employee leaves the firm, he has to be replaced. In this way the employer can no longer "distribute" the work of the person who left to the remaining ones.

If the average time account of a group is higher than e. g. 150 hours, an additional person has to be recruited ${ }^{40}$.

Another idea is to create a right of veto for the works council: If the workload is too heavy the council may intervene and ask for a remedy. In Sweden, the trade union could stop the working process, in Germany one would think about a conciliation procedure involving a conciliation board or a labour court. If it is difficult to "measure" the quantity of work then to recur to a procedure like the intervention of a works council or a union would be the better solution. If no works council has been elected, the labour inspection should intervene.

Another proposal made by a commission of the Parliament is that of so-called unattainability, i.e. the right to be unreachable during certain parts of the week ${ }^{41}$. This means a it is prohibited to contact the employee by phone or by computer e. g. after eight oclock in the evening, before seven o'clock in the morning and on weekends. Volkswagen blocks access to its servers from a quarter past six in the evening until seven oclock in the morning and on weekends. This way, nobody can check e-mails or work on the internet for official purposes. The agreement does not apply to managers. Other firms did not follow this example; in some other big enterprises it is up to the teams to decide who will be "unattainable" during the weekend or in the evening ${ }^{42}$.

\subsection{Crowdworking}

\subsubsection{Some Facts}

A German electricity company sent postcards to its customers asking them to write down the electricity counter reading and send the cards back. The way people wrote the numbers was quite different, so the computer could not read the cards in a reliable way. They decided to give the cards to human beings whose intelligence is even better than that of the computers. At an American platform, they published the task: "get 10, 000 cards and put the numbers into the system". Many people from the "crowd" (the immense number of internet users) asked for such a contract. Some of them received it, especially those who were already known by the managers

${ }^{39}$ LAG (=Landesarbeitsgericht) Berlin 24.6.2015 - 26 SaGa 1059/15 — AuR 2015, 339.

${ }^{40}$ For details see: Däubler W. AiB 2016 (in print).

${ }^{41}$ In German: "Recht auf Unerreichbarkeit”. See Enqête-Kommission. Internet und digitale Gesellschaft. Bundestags-Drucksache 17/12505; support the idea Schwemmle M., Wedde P. Digitale Arbeit in Deutschland. Potentiale und Problemlagen. Bonn, 2012. S. 87, 95; Boewe J., Schulten J. Die Mitbestimmung. 2014. Heft 4.

${ }^{42}$ For more details see: Giese J. Abschalten gegen Dauerstress, AiB 2014, issue 9, p. 64. 
of the platform. They did their job better than the computer; those who worked hard and could put many figures into the system earned two dollars an hour.

This is just an example which I remember very well because I am one of the customers. There are a lot of other fields where crowdworking takes place. One can find a lot of unqualified work. Translations are made by machines and have to be improved by native speakers. There are also tasks which require a certain intelligence, e.g. writing an article for a dictionary or describing a commodity offered by a foreign enterprise in a way that is adequate for the public. Some firms like to use a new slogan or a new logo and ask for proposals for these. Normally, only one proposal is accepted; author gets some money, and all the other people have worked for nothing. Some firms like IBM split complicated tasks into small parts which can be managed by unqualified people.

German platform "twago" has about 260,000 “collaborators", other big platform "clickworker" pretends to have 700,000. In the US there are - of course - bigger platforms like Amazon Mechanical Turk; the Australian firm "Freelancer" pretends to have 14.5 million "partners". A new estimation states 112 million crowdworkers world-wide ${ }^{43}$. In the US a lawsuit took place in which the crowdworkers demanded the legal minimum wage; unfortunately it ended with a compromise in which the lawyers got more money than the crowdworkers ${ }^{44}$.

Crowdwork offers the possibility to send work to low-wage countries without any important transaction costs; it is much less expensive than the traditional relocation. How many jobs can be replaced by outsourcing tasks in this way is unclear; even if it would only $15 \%$ or $20 \%$, it would be a kind of catastrophe for our labour market. Some estimations go up to $47 \%$.

\subsubsection{Legal Implications}

Under German law the crowdworker is no normal employee. He has to fulfil a pre-defined task and he himself decides in which moment and with which instruments he will do it. There will be only a time limit - that is all. There are no instructions given during the working process - he is a self-employed person ${ }^{45}$. Whether the description of the work in the contract itself would be equivalent to instructions given to an employee and constitute "subordination", may be considered an open question in Italy. In Germany this step has not been taken until now.

Some crowdworkers depending economically on one platform are considered to be persons "assimilated to employees" ${ }^{\text {. }}$. As it was described in the chapter on equality, only some parts of labour law apply to this group of persons.

Civil law takes place if labour law cannot be applied. The rules of the civil code give sound protection against unfair clauses put into contracts by the platforms. But the civil code guarantees no stability and no protection against the dissolution of the contract. As for the clauses, American platforms in particular use conditions which are in fundamental contradiction to European conceptions of acceptable rules laid down, for instance in the EC-directive 93/13/

${ }^{43}$ Available at: http://www.tagesschau.de/inland/crowdworking-101.html (accessed: 5. 01. 2016)

${ }^{44}$ Otey vs. CrowdFlower. The lawsuit is described by Cherry W. Regelungen zu gesetzlichen Mindestlohn im digitalen Zeitalter, in: C. Benner (ed.) Crowdwork - zurück in die Zukunft? Perspektiven digitaler Arbeit. Frankfurt/Main, 2015. P. 231 et seq.

${ }^{45}$ This is a general view in Germany based on the actual case law of the Federal Labour Court. See: Hötte I. Crowdsourcing. Rechtliche Risiken eines neuen Phänomens, Multimedia und Recht. 2014, 796; Klebe T., Neugebauer J. Crowdsourcing Für eine Handvoll Dollar oder Workers of the Crowd Unite? AuR 2014, 5; Däubler W. Crowdworker — Schutz auch außerhalb des Arbeitsrechts? in: C. Benner (ed.). Op. cit. S. 246.

${ }^{46}$ See 3.1 above. 
$\mathrm{EEC}^{47}$. For example, the platform reserves the right to refuse the work done by the crowdworker and to pay nothing without giving reasons. If corrections are needed, they have to be done within two or three days; if this delay is not observed, the worker will lose the right to get paid. Another point: as crowdwork is the main source of income for two thirds of the workers it does not seem adequate, to get money only if you are the winner; this is the case if one performs a more sophisticated task like the development of a logo. A "lottery" is not an adequate form of salary. Additionally, even those who don't become "winners", have to transfer all their intellectual property rights to the platform. A German court would never accept such a clauses, even if the foreign platform includes a provision that American law applies ${ }^{48}$.

\subsubsection{Perspectives}

Crowdworkers do their job in quite isolated situations - comparable to homeworkers in the past. Experience shows that it is quite difficult to achieve a common action under such circumstances. What can be done to improve the situation for crowdworkers? Better protection will perhaps make this alternative less attractive for employers, which could be useful for workers in traditional jobs, too.

The first step should be that crowdworkers communicate with each other and make their individual problems known to other people. In the US some people have established "turkopticon", a platform for crowdworkers who have contracts with Amazon Mechanical Turk (AMT). As different firms put their offers on the AMT-platform, there will be "good ones" paying a reasonable price and paying on time, and there will be "bad ones" who pay low sums and do so rather less timeously. Contracts with the "bad ones" can be avoided. In extreme cases there can be a boycott in the sense that nobody will contact a firm having a very bad reputation. Thus, over-exploitation would be made impossible ${ }^{49}$.The German metalworkers' union (IG Metall) has established a comparable forum over the internet; crowdworkers may contact www. faircrowdwork.com, communicate their experiences and ask for advice. The German service union offers such a service, to ${ }^{50}$. The internet makes it easier for individuals to avoid isolation.

What is the next step? Extend the notion of 'employee' to crowdworkers and make labour law applicable? In Germany this will be a task for courts as the legislator will hesitate. But court decisions have to be prepared by a general discussion among lawyers as well as the media: if television shows that crowdworkers really earn only 2 Euros an hour a court will perhaps be inclined to change the situation. The academic discussion has its importance, too. And one should find persons who are willing to defend their rights in court - no easy task if the concerned persons are anxious to get contracts any more.

Labour law as such offers better possibilities to improve the situation of crowdworkers but there is no guarantee that this will happen. How can collective agreements be reached? Or how can minimum standards be reached if the courts do not accept labour law being applied? The pressure of public opinion may be quite important, even more important than the traditional means of a strike which would be difficult to organize. We have to look for examples of how people in a comparative situation managed to reach minimum standards. One can refer to the

${ }^{47}$ OJ 21.4.1993, L 95/29.

${ }^{48}$ As to details about illegal clauses see Däubler W. (above note 43).

${ }^{49}$ How turkopticon functions is described at Irani L., Silberman M. Ein Tool, um Arbeiter auf Mechanical Turk sichtbar zu machen. C. Benner (ed.). P. 131 et seq.

${ }^{50}$ Available at: http://www.ich-bin-mehr-wert.de/support/cloudworking (accessed: 5.01.2016) 
case of 74,000 home-care aids in California who were able to build their own union and get much better conditions ${ }^{51}$. Another example may be the National Day Labour Organizing Network, a new form of union: instead of organizing traditional collective action the organisation gives information to its members about prices in the market and about good and bad employers, with the bad ones risking getting no day workers any more ${ }^{52}$. We can find the same principle in the movement of the "travelling journeymen" (called in German: "Gesellenbewegung") which has existed in Central Europe since the $13^{\text {th }}$ century. Bad employers, i. e. (at that time) craftsmen, were formally "discredited"; no journeyman could conclude a contract with them without being discredited, too ${ }^{53}$. The boycott replaces the strike and other means of collective actions. Its mere existence presents a very important incentive to employers or entrepreneurs to offer fair conditions. Obviously, we have to broaden our horizons in order to find adequate answers.

Today, the framework for discussion about improving the situation of crowdworkers is quite a traditional one: How can we manage to reach a comparable level of protection to that which is currently given to employees in an office? This is important, without any doubt. But would it not be necessary to think about the future in a digitalized society? What does it mean for our lives to be surrounded by the internet of things? Are we just going to accept or copy whatever is developed in Silicon Valley? Or should we have an alternative model of the digitalized society, something like a left-wing utopia? It is not the task of labour lawyers to develop it, but we could and we should offer our contribution.

\section{I国 References}

Benner C. (Hrsg.) (2015) Crowdwork-zurück in die Zukunft? Perspektiven digitaler Arbeit. Frankfurt/ Main: Bund-Verlag, $420 \mathrm{~S}$.

Boewe J., Schulten J. (2014). Recht auf Abschalten. Die Mitbestimmung, issue 4. Available at: www. boeckler.de (accessed: 5.01 .2016 )

Conaghan J., Fischl R., Klare K. (2000). Labour Law in the Era of Globalisation. Transformative Practices and Possibilities. Oxford: Oxford University Press, $546 \mathrm{p}$.

Däubler W. (Hrsg.) (2011). Arbeitskampfrecht. 3 Aufl. Baden-Baden: Nomos, 1005 S.

Däubler W. (2014). Entgrenzung der Arbeit, ein Problem des Arbeitsrechts? Soziales Recht. S. 45-65.

Däubler W. (2015). Das Arbeitsrecht. 11 Aufl. Frankfurt/Main: Bund-Verlag, 591 p.

Däubler W., Müller W. (2015) Chinesische Arbeitgeber in Deutschland. Arbeitsrecht im Betrieb. Heft 2, S. 33-36.

Fröbel F., Heinrichs J., Kreye O. (1977). Die neue internationale Arbeitsteilung. Reinbek near Hamburg: Rowohlt, $653 \mathrm{~S}$.

Giese G. (2014) Abschalten gegen Dauerstress. Arbeitsrecht im Betrieb. Heft 9, S. 64-66.

Gorelli-Hernández J. (coord.) (2014). El Derecho a la Negociación Colectiva. Liber Amicorum Profesor Antonio Ojeda Avilés. Sevilla: Consejo Andaluz de Relaciones Laborales, 567 p.

Hepple B., Veneziani B. (eds.) (2009). Transformation of Labour Law in Europe.

Oxford: Hart Publishing, $393 \mathrm{p}$.

Hötte D. (2014). Crowdsourcing. Rechtliche Risiken eines neuen Phänomens. Multimedia und Recht, pp. 795-798.

${ }^{51}$ More details see at Klare. The Horizons of Transformative Labour and Employment Law, in: Conaghan/ Fischl/Klare. Labour Law in an Era of Globalization. Transformative Practices \& Possibilities. Oxford, 2000. P. 20 et seq.

${ }^{52}$ See http://ndlon.org. Details at: Däubler Representation of Workers' Interests Outside Collective Bargaining, in: Hernández G., coord. El Derecho a la Negociación Colectiva. Liber Amicorum Profesor Antonio Ojeda Avilés. Sevilla, 2014. P. 99 et seq.

${ }^{53}$ See Däubler W. (ed.). Arbeitskampfrecht. 3. Aufl. Baden-Baden, 2011. $\$ 1$ Rn. 5 et seq. 
Klebe T., Neugebauer J. (2014). Crowdsourcing: Für eine Handvoll Dollar oder Workers of the Crowd Unite? Arbeit und Recht. S. 4-7.

Müller-Glöge R., Preis U., Schmidt L. (Hrsg.) (2016). Erfurter Kommentar zum Arbeitsrecht. 16 Aufl. München: Beck-Verlag, $2938 \mathrm{~S}$.

Pfromm H.-A. (1978). Solidarische Lohnpolitik. Köln: Bund-Verlag, 135 S.

Schulten Th. (2001). Solidarische Lohnpolitik in Europa. WSI- Diskussionspapier (Discussion paper) No. 92. Available at: www.boeckler.de (accessed: 12.11.2015)

Schwemmle M., Wedde P. (2012). Digitale Arbeit in Deutschland. Potentiale und Problemlagen. Bonn: Friedrich-Ebert-Stiftung, $145 \mathrm{~S}$.

Wilkinson R., Pickett K. (2010). The Spirit Level. Why Equality is Better for Everyone. London: Penguin, $375 \mathrm{p}$. 